日臨外医会誌 53 (12)，3017-3021，1992

症例

症状を欠くステロイド産生副腎皮質癌の 1 例

山口大学第 1 外科 (主任：汇里健輔教授)

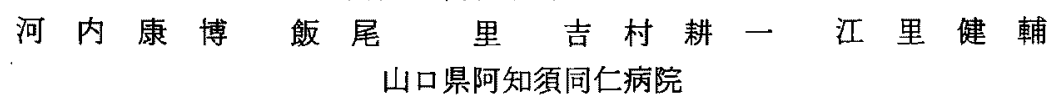

西田健一

症例は61葴の女性で，全身倦怠感，嗄声をきたし，精査目的に入院した，左前頸部に 表面平滑，弾性軟の甲状腺腫を触知し，画像診断で良性甲状腺腫と判断した。しかし腹 部超音波娭查で脾と左腎との間に境界明瞭，不均一な内部エュー像を呈する $9 \times 7 \mathrm{~cm} の$ 充実性腫瘤を認めた。CT, MRIでは, 境界明瞭, 内部は添济均一な副腎腫瘍と考えられ た.内分必学的検查では血中 DHEA-sulfate, プロゲステロン括よび尿中17-KS が高值を 示した，甲状腺腫を合併した症状を欠くステロイド産生副腎皮質腫場の診断で左副腎摘


ていた。割面は褐色, 弾性軟の充実性腫湯で, 出血や埭死巣を散在性に認めた。病理組 織学的には副腎皮質癌と診断された。

卖引用語：副腎皮質癌

はじめに

副腎皮質癌はきわめて稀な疾患とされている。副腎 皮質癌は畽瘍の産生したステロイドにより,“ステロイ ド過剩による症状をあらわす内分泌活性癌”之“ステ ロイドを合成しない非活性癌”に分けられ，腫瘍がス テロイド合成しても，そのための臨床症状を欠くる のを“症状を欠くステロイド産生腫瘍”とされている. 今回われわれは，甲状腺腫を合併した症状を欠くステ ロイド産生副腎皮質癌の 1 例を程験したので若千の文 献的考察を加壳て報告する。

症例

患者：61歳，女性。

主訴：全身億总感, 㖽声.

既往歴：48歳, 子宮筋腫にて子宮全摘術.

家族歷：母，姉が胃癌で死亡。

現病歴: 平成 2 年10月頃より嗄声をきたすように なった. 平成 3 年 3 月頃より全身倦怠感, 腰痛を伴 ようになり, 平成 3 年 4 月19日精查目的に入院となっ た.

入院時現症：身長 $151 \mathrm{~cm}$ ，体重48kg，血王101/63 $\mathrm{mmHg}$, 脈拍 $63 /$ 分, 整, 体温 $36.2^{\circ} \mathrm{C}$. 負血, 黄疸なく,
左前頸部に讌下運動と共に上下に動く表面平滑, 弾性 軟の腫瘤を触知した。頸部リンバ節は触知されなかっ た。胸部には異常所見は認められなかった。腹部は平 坦であったが，左上腹部に王痛を伴った畽瘤様抵抗を 認めた，肝，脾は触知されなかった，また皮膚，外陰， 乳房の変化等はなかった。

入院時検查所見：血液一般検査では血沈が $20 \mathrm{~mm} / 1$ $\mathrm{hr}, 51 \mathrm{~mm} / 2 \mathrm{hr}$ と軽度え進を示した以外正常範用内で, 腫助マーカー，尿所見異常なかった。また状腺機 能桧查では $\mathrm{T}_{3} 1.3 \mathrm{ng} / \mathrm{ml}, \mathrm{T}_{4} 29 \mu \mathrm{g} / \mathrm{dl}$, TSH $2.1 \mu \mathrm{IU} /$ $\mathrm{ml}$, サイログロブリン $52.3 \mathrm{ng} / \mathrm{ml}$ でいずれも正常範囲 内であった。

入脘後経過：甲状腺 CTスキャン扛上び超音波検査 では，甲状腺左葉に一致して $28 \times 25 \mathrm{~mm} の$ halloを 伴った均一な充実珄腫㨨があり，内部に不整形の䑟胞 を諗めた，石灭沈着は認められなかった。甲状腺シン チ $\left.{ }^{{ }^{99 m}} \mathrm{TcO}_{4}{ }^{-}\right)$では腫焬に一致して cold nodule を示 した. ${ }^{201} \mathrm{Tl}$ シンチでは early phase で hot noduleを 呈し, delayed phaseでは集積は認められなかった。嗄 声に関しては，耳畺科を受診し両ポリープ様声帯炎， 副鼻腔炎の診断で治療された。 上部消化管，大腸の透 視および内視鏡検查では異常を認めなかった。しかし 腹部超音波検查で脾と左腎との間に境界明瞭，不均一

1991年12月24日受付 1992年 9 月30日採用 

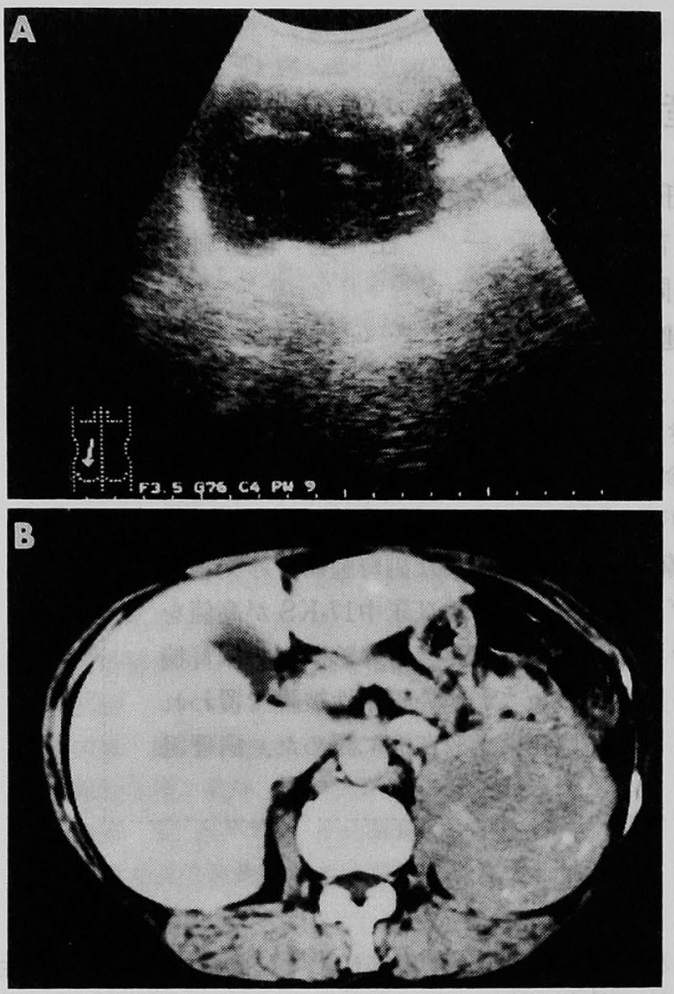

図 1 腹部超音波検査およひ腹部 CT：脾缄と左腎と の間に境界明瞭, 不均一な内部エコー像を呈する $9 \times$ $7 \mathrm{~cm}$ の充実性腫瘤を認めた（A)．CT では辺縁境界 明瞭な充実性腫瘤を認め, その内部は均一で散在性 に石灰化を認めた。エンハンス CT では，内部は軽 度の錯綜する線状の造影および変性を示唆する低吸 収巣を認めた（B）。

な内部ェコー像を呈する $9 \times 7 \mathrm{~cm}$ の充実性腫瘤を認め た。腹部 CTです，辺縁境界明瞭な充実性腫瘤を認め， その内部は均一で散在性に石灰化を認めた。エンハン ス CT では，腫瘤内部は俥度に錯綜する線状の造影抏 よび変性を示唆する低吸収巣を呈した（図 1 ）。

MRI では， $\mathrm{T}_{1}$ 強調像で車湯は中等度の均一信号を 示し, $\mathrm{T}_{2}$ 強調像で高度の信号強度を示し, 内部はほほ 均一で錯綜する血管の帯状低信号域を示した（図 2 ）. 腹部大動脈造影では，左腎動脈は下方に延長扰よび偏 位しており，静脈相にて左腎上極に腫瘤陰影を認め， さらに下副腎動脈は抁張し血管増生を伴っていた（図 3).

内分泌学的検查: 血中コルチジール, DHEAsulfate，プロゲステロン扰よび尿中17-KS が高值を示
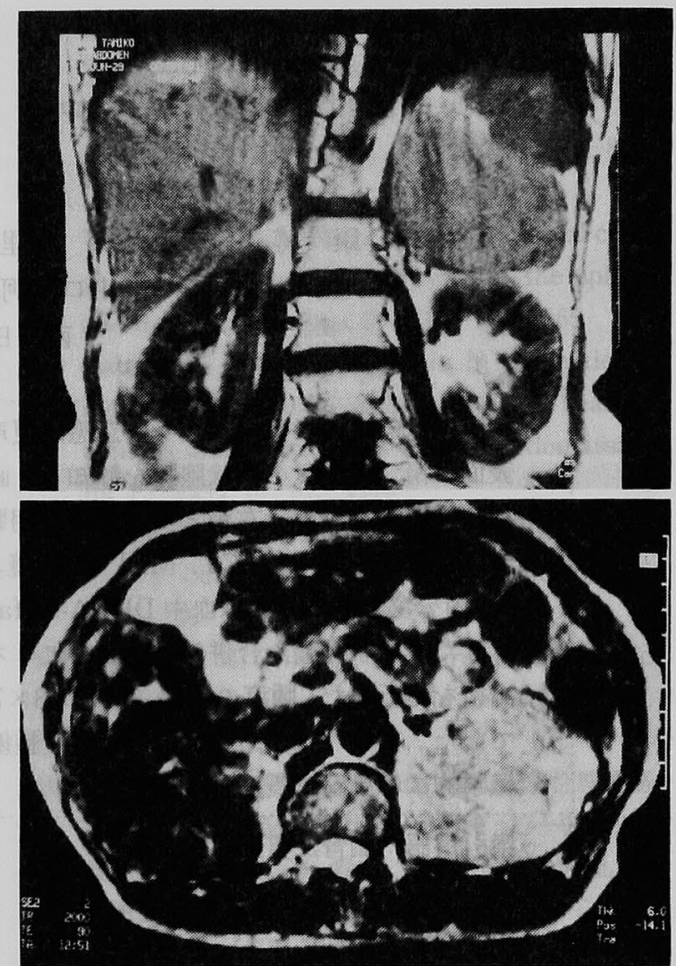

図 2 MRI： $T_{1}$ 強調像で腫湯は中等度の均一信号を 示し (A), $T_{2}$ 強調像で高度の信号強度を示し, 内部 はほぼ均一で錯綜する血管の带状低信号域を認めた (B).

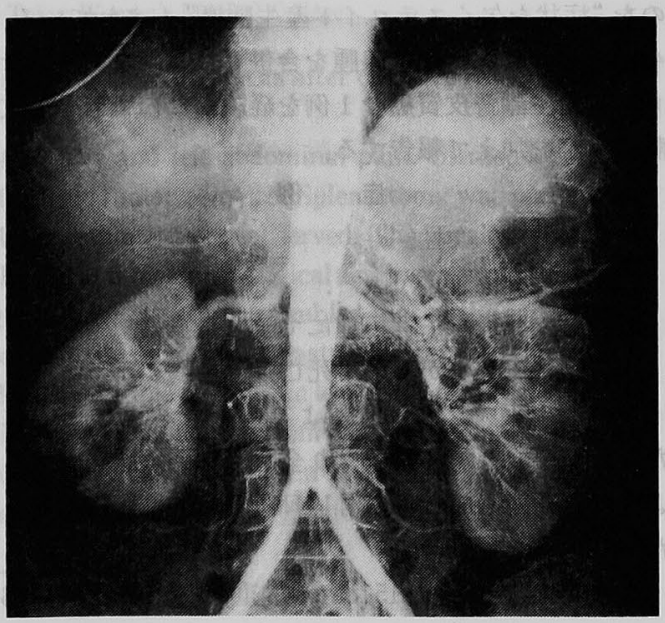

図3大動脈造影：左留動脈は下方に延長および偏位 しており，静脈相にて左腎上極に腫瘤陰影を認め， さらに下副腎動脈は拡張し血管増生を伴っていた。 
表 1 内分泌学的検查成繶

\begin{tabular}{|c|c|c|c|}
\hline 血 & 中 & 尿 & 中 \\
\hline 血永レンン活性 & $1.2 \mathrm{ng} / \mathrm{ml}(0.5-2.0)$ & 17-OHCS & $5.4 \mathrm{mg} /$ day $(2.6-78)$ \\
\hline コルチゾール & $15.9 \mu \mathrm{g} / \mathrm{dl}(2.7-15.5)$ & $17-\mathrm{KS}$ & $82.9 \mathrm{mg} /$ day $(1.0-8.0)$ \\
\hline プロゲステロン & $1.1 \mathrm{ng} / \mathrm{ml}(0.1-0.2)$ & アルドステロン & $1.6 \mathrm{ng} / \mathrm{ml}(1.5-10.4)$ \\
\hline ブレグネノロン & $1.1 \mathrm{ng} / \mathrm{ml}(0.1-1.5)$ & アドレナリン & $16 \mu \mathrm{g} /$ day $(2-30)$ \\
\hline DHEA-sulfate & $8092 \mathrm{ng} / \mathrm{dl}(400-1500)$ & ハルナドレナリン & $131 \mu \mathrm{g} /$ day $(25-120)$ \\
\hline
\end{tabular}

した（表 1 ).

以上の所見により良性甲状腺腫を合併した症状を欠 くステロイド産生副腎皮質腫瘤と診断したが， ACTH，デキサメサゾン抑制試験を行わなかったので 過形成か悪性腫瘍かの鑑別は出来なかった。そこで, 左副腎摘出術を施行した。

手術時所見：上腹部正中切開にて開腹し, splenic flexure 上方で後腹膜腔に達した. 左腎上部に超手拳大 の腫瘤を確認した，腫瘤は充実性で，被膜を有し周曲 への浸潤は認められなかった，腫瘤は鈍的鋭的に周曲 組織より䟝離可能で, 正常な副腎組織を含めて完全摘 出した. 尚, 大動脈周囲リンパの腫大はなく, 腹水も なかった。

摘出標本所見：畽瘤の大きさは $10 \times 8 \times 7 \mathrm{~cm}$, 重さ $295 \mathrm{~g}$ で，薄い線維性被膜で覆われていた，割面性状は 褐色で, 弾性軟, 充実性で, 出血や壊死巣を散在性に 認めた（図4）.

病理組織所見：中型のややクロマチンに富む核を有 し，好酸性の豊かな胞体をもった腫瘍細胞が，血管腔 を基質として胞巣状に増生していた。一部で核の大小 不同を認め，異常核分裂像も散見された。また細胞变 珄像とその部における石灰化や被膜への浸潤も一部に 認めた. 以上の所見より，副腎皮質癌と診断された(図 5 ).

術後経過：術後左胸膜炎, メニエール病を合併した が，保存的治療で軽快した，組織学的診断から，5-FU を150mg/day 経口投与で開始した。 また，術前高值を 示した内分泌学的検査値は全て正常値となった。全身 状態が安定して甲状腺腫に対し甲状腺腫摘出術を施行 し, 組織学的には濾胞腺腫であった，左副腎摘出術後 6 カ月の現在, 再発の徵候はなく, 笅重に経過観察し ている.

\section{考察}

副腎皮質癌は，日本剖検集報で全悪性腫瘍の $0.17 \%$ というきわめて稀な疾患である゙．内分泌活性型副腎 畽煌は症状を捛こすステロイドおよびその代謝物が血

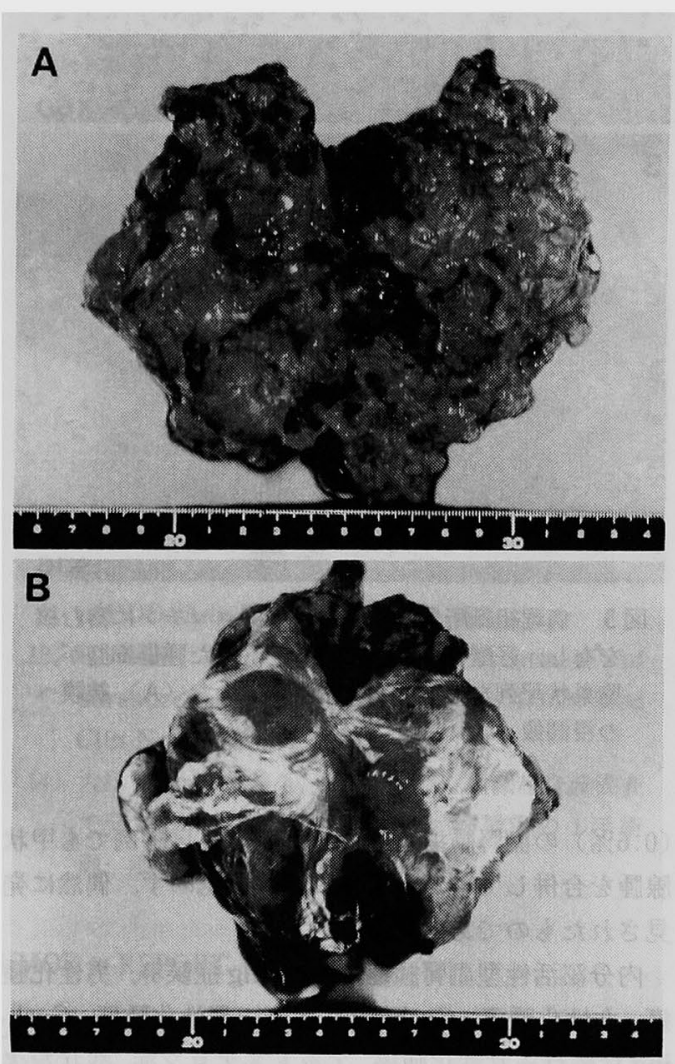

図 4 摘出標本所見 : 腫湯の大きさは $10 \times 8 \times 7 \mathrm{~cm}$, 重 さ295g で，薄い線維性被膜で覆われていた。割面性 状は褐色, 弾性軟, 充実性で, 出血や買死巣を散在 珄に認めた。

中や尿中に見いだされる。一方内分泌非活性型副腎腫 瘍は，内分泌による特異的臨床症状を呈しないため臨 床診断は困難である. 症状として発熱, 腹痛, fatigue syndrome（易疲労感, 全身倦㤐感, 発汗, 体重减少, 食思不振), 腹部尰瘤や転移に随伴する症状などが知ら れている2). しかし, 近年の画像診断法の発達, 普及に より，偶然に発見される副腎重瘍が増加している3． Glazer ら4)は, 2,200人の腹部 CT スキャンで14人 


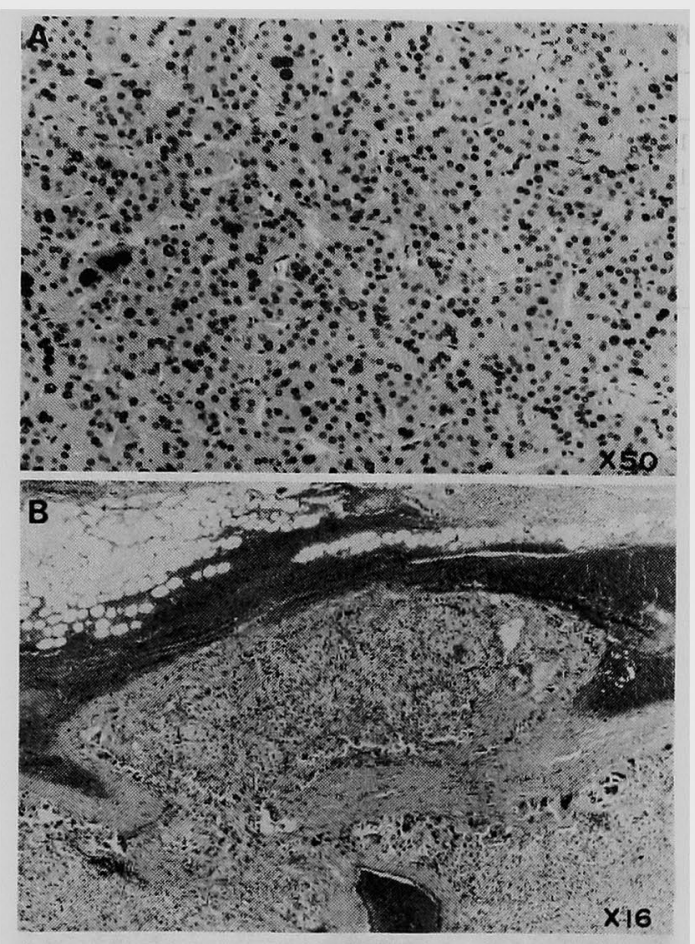

図 5 病理組織所見：中型のややクロマチンに富む核 を有し，好酸珄の豊かな胞体をすった腫瘍細胞が， 胞巣状配列をとって密に増生していた（A). 被膜へ の漫潤像 (B).

(0.6\%) の副腎腫瘍を発見している，自験例でも甲状 腺腫を合併していたが，特に症状を認めず，偶然に発 見されたものであった。

内分泌活性型副腎董湯は Cuscing 症候群, 男性化腫 瘍，女性化腫瘍，Cushing 症候群十男性化腫瘍, Cushing 症候群十女性化腫瘍, アルドステロン症, 症状を欠 くステロイド産生腫瘍に分類される゙，副豎腫瘍の内 分泌臨床症状は, 分泌されるホルモンの種類, 分泌量, 生物活性の程度により決定される、副腎皮質癌では 種々のホルモンが大量に分泌排泄され Mixed syndromeを呈することが多いが，男性ホルモン，女性ホ ルモン両方が過剩分泌され，一見内分泌症状を呈さな かった症例の報告もある5!.内分泌活性型副腎腫瘍の 内分泌学的診断の特徵は尿中17-KS, 17-OHCS が高値 を示し，特に17-KS の異常高値は特徵的とされ，その 他 ACTH 刺激試験, Dexamethazone 抑制試験は原則 として無反応とされている，自験例ではステロイド中 間代謝産物である DHEA-sulfate，さらにコルチゾー
ル,プロゲステロソ扰び尿中17-KS が高值を呈した が,これらのステロイドは生物活性にそしいため内分 泌症状を呈さないものと考えられ，症状を欠くステロ イド産生副腎皮質腫瘍と診断した。

副腎皮質腫瘍で臨床的に問題となるのは悪性腫疸と の鑑別である、副腎皮質腫陽で長径 $5 \mathrm{~cm}$ 以上の場合は 癌が疑われると報告している゙が，必ずしす大きさだ けからの判断は困難である。副腎皮質癌の場合，腫瘍 内部の出血, 壊死，それに伴う石灰化，周囲への浸潤 が特徵で7), 画像上, 内部構造の不均一や境界不明暸之 して描出される。血管造影所見では，副腎皮質癌の多 くは血管に富み，腫湯血管像や染色像が認められ，逆 に良性腫癔の場合は腫瘍血管は少ないとされる8)。乙 かし，良性の腺腫でも腫䀛血管に富む例もあり鑑別困 難である. 最近 Reinig ら9， MRI で副腎腫瘍の良性 か悪性かの鑑別が可能としているが，さらに検討を要 する。

病理組織学的所見から副腎腫場の良性・悪性を区別 することは困難で，組織像で良性と診断されたにすか かわらず術後広範な転移をきたし，半年後に死亡した 例も報告されている(14). Heinbecker $5^{10)}$ は, 覀性の診 断基準として，1）高度の核分裂像，2）出血ならびに 壊死，3）静脈内への浸潤，4）被膜を越えての浸潤， 5）遠隔転移をあげており，異型性の乏しい細胞が規則 正しい配列を示していても，静脈浸潤や被膜浸潤が存 在する時は悪性の経過を示すと報告している。 Weiss ${ }^{11}$ は43例の副腎皮質腫瘍を retrospectiveに検 討し, 転移 - 再発群 (18例) と非転移・非再発群（25 例)に分け,病理組織学的に 9 項目について比較を行っ た，転移・再発群では，1）核の異型度が強い，2）核 分裂の数が高倍率50視野で 6 個以上, 3) 異型核分裂像 の存在，4）淡明細胞の割合が25\%以下，5）びまん性 の腫湯細胞の増生，6）壊死单の存在，7）静脈浸潤, 8）毛細胞管漫潤，9）被膜浸潤の5ち 4 項目以上を満 たし，非転・非再発群では 2 項目以下であったと述べ ている. 自験例では9項目のうち1)3)4)6)9)の 5 項目 を満たし，Weissの分類では転移・再発群の組織所見 に一致した。

副腎皮質癌の治療は，外科的摘除が第一であるが， 根治的に摘除されたと考えられる例でも転移あるいは 再発をきたすことがある，術後の補助療法として，化 学療法や放射線療法が行われているが，いずれもあま り効果は期待できない. 化学療法としては, 副腎皮質 の壊死萎縮をおこす0, $\mathrm{p}^{\prime}$-DDD が Bergenstal ら ${ }^{12)}$ の臨 
床報告以来多く使用されているが，効果は一定してい ない. Hoffmann $b^{13)}$ は，進行癌で末期的時期や内分必 過剩による症状の改善を目的とする場合のみ投与すべ さであると報告している，その他，5-FU，CDDP，ア ルキル化剤などあ単独または併用されているが，十分 な効果はみられていない.

予後は亟めて不良で，そのほとんどが 1 年以内に死 亡している14).このように副腎皮質癌に対して, 手術療 法以外の治療法に決め手を欠く現状では，早期発見， 外科的摘除が最む重要である。

\section{結語}

われわれは，甲状腺腫を合併した症状を欠くステロ イド産生副孯皮質癌の 1 例を経験したので若干の文献 的考察を加えて報告した。

\section{文献}

1）岛崎 淳, 伊藤睛夫，山口邦夫他：副腎艆，日臨 $41: 1383-1391,1983$

2）田村 泰, 大橋教良, 岩本逸夫他：副腎皮質癌の臨 床, 癌の臨 $20: 839-845,1974$

3）佐藤辰男，森岡由釈，井上準之助他：CT スキャン により偶然に発見された副腎腫湯一頻度, 種類な らびに対応について，内科 61:741-746, 1988

4) Glazer HS, Weyman PJ, Sagel SS, et al: Nonfunctioning adrenal masses, incidental discovery on computed tomography. Am J Roentgenol $139: 81-85,1982$

5）橋本隆彦，永并良二，本多英邦他：内分泌非活性副 惄皮質癌の電子顕筇鏡的観察，日外会誌 $81: 99$ ，
1980

6) Rosai J: Ackerman's surgical pathology. Mosby St Louis, 1981

7) Vermess M, Schour L, Jaffe E: Classification in benign nonfuctioning adrenal adenoma. Report of a case with selective adrenal arteriogram. Brit J Radiol 45:621-623, 1972

8）林 邦昭, 前田宏文, 福鸠藤平他：副腎癌の血管造 影診断, 臨放線 $24: 855-860,1979$

9) Reinig LW, Doppman JL, Dwyer AL, et al: Distinction between adrenal adenomas and metastases using MR imaging. J Comput Assist Tomogr 9: 898-901, 1985

10) Heinbecker $P, O^{\prime} N e a l$ LW, Ackerman LV: Functioning and non functioning adrenal cortical tumors. Surg Gynec Obst $105: 21-33,1957$

11) Weiss LM: Comparative histologic study of 43 metastasizing and nonmetastasizing adrenocortical tumors. Am J Surg Pathol $8: 163$ $-169,1984$

12) Bergenstal DM, Hertz $R$, Lipsett $M B$, et al : Chemotherapy of adrenocortical cancer with o, p'-DDD. Ann Int Med $53: 672,1960$

13) Hoffman DL, Mattox VR: Treatment of adrenocortical carcinoma with o,p'-DDD. Med Clin North Am 56: 999-1012, 1972

14)大江毅, 加藤善久, 原田 尚他：腹部超音波検查 で発見された内分必非活性型副腎腫湯の 1 手術 例，癌の臨 $36: 1377-1380,1981$

\title{
FUNCTIONING ADRENOCORTICAL TUMOR -REPORT OF A CASE-
}

\author{
Yasuhiro KOUCHI, Sato ITO, Kouichi YOSHIMURA, Kensuke ESATO and Kenichi NISHIDA* \\ First Department of Surgery, Yamaguchi University School of Medicine \\ * Department of Surgery, Azisudozin Hospital
}

A 61-year-old female was admitted to the hospital because of general fatigue and hoaresness. An elastic soft, smooth surfaced and nontender mass was palpable in the left lobe of the thyroid gland. Radiographic examinations revealed a benign thyroid adenoma. Abdominal ultrasonography, however, a $9 \times 7 \mathrm{~cm}$ solid tumor presenting as well-defined heterogenous internal echoic picture between the spleen and left kidney. CT and MRI indicated a well-defined homogenous adrenal mass. In endocrinologic examination elevated serum DHEA-sulfate, progesteron, and urinary 17-KS were noted. Functioning adrenocortical tumor was suspected and adrenalectomy was performed. The removed adrenal tumor was $10 \times 8 \times 7 \mathrm{~cm}$ in sizeand $295 \mathrm{~g}$ in weight and covered with thin fibrus capsule. Its cut surface was brown. It was a elastic hard and solid tumor, scatering with hemorrhagic and necrotic lesions. Histologically the tumor was adrenocortical carcinoma. The patient is well as of half year after the operation. 